Article

\title{
"They All Lived Happily Ever After. Obviously.": Realism and Utopia in Game of Thrones-Based Alternate Universe Fairy Tale Fan Fiction
}

\author{
Anne Kustritz \\ Department of Media and Culture Studies, Utrecht University, Muntstraat 2A \#1.09, Utrecht 3512 EV, \\ The Netherlands; a.m.kustritz@uu.nl; Tel.: +31-30-253-8300 \\ Academic Editor: Claudia Schwabe \\ Received: 1 April 2016; Accepted: 7 June 2016; Published: 9 June 2016
}

\begin{abstract}
Fan fiction alternate universe stories (AUs) that combine Game of Thrones characters and settings with fairy tale elements construct a dialogue between realism and wonder. Realism performs a number of functions in various genres, but becomes a particularly tricky concept to tie down in fantasy. Deployments of realism in "quality TV" series like Game of Thrones often reinforce social stigmatization of feminine genres like the romance, melodrama, and fairy tale. The happily-ever-after ending receives significant feminist criticism partly because it falls within a larger framework of utopian politics and poetics, which are frequently accused of essentialism and authoritarianism. However, because fan fiction cultures place all stories in dialogue with numerous other equally plausible versions, the fairy tale happy ending can serve unexpected purposes. By examining several case studies in fairy tale AU fan fiction based on Game of Thrones characters, situations, and settings, this paper demonstrates the genre's ability to construct surprising critiques of real social and historical situations through strategic deployment of impossible wishes made manifest through the magic of fan creativity.
\end{abstract}

Keywords: realism; fantasy; fairy tales; fan fiction; feminism; queer theory; television; transmedia; utopia

\section{Introduction}

Once Upon a Time and Game of Thrones, which both premiered in 2011, each portray themselves as, at least, partly realistic medieval-based fantasy worlds in contrast to "traditional" fairy tales $[1,2]$. Yet, while HBO's ${ }^{1}$ Game of Thrones largely conveys realism through graphic sex, violence, and a dystopian refusal of anything approaching a "happy ending", Once Upon a Time uses a network-approved form of melodrama to muddy up familiar fairy tale characters' motivations. Once Upon a Time parodied this tonal dichotomy in the finale of its fourth season, when a magical plume sent the characters into a dark alternate universe very much like Game of Thrones where, as one character explained to another, "It's cold, there's no running water, and things are always trying to kill you" [3]. Yet, despite its protests and pretensions, Game of Thrones' realist narrative contains numerous fairy tale tropes and references, which offer fans clear openings to enact their own genre displacement of the narrative and imagine different possible futures. By examining fan-written fairy tale versions of Game of Thrones, these continuities become increasingly clear. This project thus unravels the consequences of Game of Thrones' characteristically quality TV construction of realism through the normative principles of intelligibility and probability, separating that which may be culturally received as realistic from that which becomes unrealistic in contrast. The project then investigates feminist, queer,

$1 \mathrm{HBO}$, or Home Box Office, is an American premium cable channel. 
and historical criticism of one particularly "unrealistic" fairy tale trope: the "happily-ever-after" ending with its tendencies toward proscriptive normative closure, as it interacts with fan fiction distribution networks that enable narrative proliferation. Finally, the paper then examines five examples of Game of Thrones-based fairy tale AU (alternate universe) fan fiction, demonstrating the range of fan fiction authors' experimentation with fairy tale tropes. By juxtaposing Game of Thrones and fairy tales, modern fan authors reflect on the conditions of modern and historical life, expressing otherwise unrealistic political, sexual, and cultural possibilities through the language of magic and wonder.

\section{Quality TV and the Riddle of Realism}

As argued by Michael Newman and Elana Levine, contemporary "quality TV" like Game of Thrones legitimates itself through several strategies, including realism, to substantiate its claims to social, political, and artistic merit [4]. The fairy tale, on the contrary, often functions as cultural shorthand for unrealistic idealism, as discussed by Vanessa Joosen [5]. The clichéd phrase, "this isn't a fairy tale" generally indicates, in the vernacular, that things are about to "get real", typically meaning dark, complicated, and decidedly unhappy. Programs like Game of Thrones thus inhabit a place within a much longer conversation on the meaning and construction of realism and cultural value, and, as a result, these longstanding internal contradictions of realist representation play themselves out within Game of Thrones' narrative and reception, as well as in fan rewrites. The significance of fan writing that reframes Game of Thrones within a fairy tale narrative thus pivots upon the contested meaning of realist storytelling, especially within the context of gendered genres and the history of queer and feminist forms of fairy tale revision. Such tales, when placed within fan distribution networks, may recuperate both the pleasures and politics of stories beyond the bounds of what contemporary "quality TV" deems realistic, particularly when realism is defined through the normative criteria of the intelligible and the probable.

The question of realism in television has long been tangled up in intersecting hierarchies of taste, quality, gender, and the politics of the possible. While many classic scholars of television, such as Raymond Williams, preferred sociological over aesthetic study of the medium as part of a critical approach to the social violence inflicted by taste cultures, which often brands all TV as low culture trash, analysis of so-called "quality TV" and television's cultural value has become increasingly important to the field and the industry [4,6-14]. Scholars, including Cristine Geraghty, argued that value judgments are necessary to understand how most people think about TV, while others began mapping out specific criteria by which quality might be measured in a genre- and medium-specific manner, such as Jason Mittel's work on "complex TV" [7,11]. For Robert Thompson, quality TV most often, "creates a new genre by mixing old ones ... tends to be literary and writer-based...The subject matter...tends towards the controversial [and]...it aspires toward 'realism'" ([15], pp. 14-15). Although Thompson wrote in 1996 about network TV programs like Hill Street Blues and ER, his description maps closely onto Game of Thrones and the branding strategies of contemporary cable companies that market themselves as a quality alternative to network TV, most notably $\mathrm{HBO}$ whose catch phrase for over ten years was "It's not TV. It's HBO" [4,10]. Realism of some description thus functions as one of the key criteria by which the quality of television has come to be judged, and the definition of realism thereby also becomes a critical question in understanding the cultural position of modern television programs and their associated fan works.

Game of Thrones neatly sutures several of Thompson's criteria for defining realism, and its media reception begins to suggest the problematic excisions performed by quality TV's claims to represent realistic subject matter. Based on a genre-defying series of books known for appropriating and questioning aspects of fantasy, fairy tale, and historical fiction, Game of Thrones nicely meets Thompson's requirement that quality programs are literary and challenge genre conventions. Yet, most importantly for this inquiry, Thompson groups together the requirement that quality programs employ controversial subject matter and a realist aesthetic, what Kim Akass and Janet McCabe call the ironic nexus of "sex, swearing, and respectability" [6,15]. Known for its gritty quasi-mediaeval storyworld 
overflowing with graphic sex, graphic violence, and graphic sexual violence, subject matter allowed only on cable by American broadcast censors, Game of Thrones draws on both controversy and realist claims to secure its place within $\mathrm{HBO}^{\prime}$ 's pantheon of quality dramas [16]. As a mark of its success, the series has become a critical darling, heralded in articles that emphasize its realism and applicability to actual political and social issues with titles like: "Why Game of Thrones is More than Fantasy," "How Game of Thrones Teaches Us About the Syrian Refugee Crisis," and "The Real Human History Behind Game of Thrones" [17-19]. Key to Game of Thrones' positioning in this respect is its frequently cited basis in real history, namely the War of the Roses in mediaeval England. These realist historical bonafides are frequently discussed in interviews with the author, George R. R. Martin, and form the basis of significant fan activity, including the website "History Behind Game of Thrones", dedicated to voluminous excavation of the historical basis for the series' characters and plots, as well as educational videos like TedTalk-sponsored "The Wars that Inspired Game of Thrones" [20-22]. Coupled with its reliance on graphic subject matter, Game of Thrones thus exemplifies the quality TV implication that reality is inherently too dark for network TV.

Yet, realism can also be a surprisingly difficult quality to pin down. Luc Herman's Concepts of Realism begins with the observation, "Realism in literature can mean a great many things" ([23], p. 9). The aesthetics and politics of realism have long been in dispute, and for nearly as long realism has been tied to claims about seriousness and quality. Take, for example, Andrew Higson writing in Screen in 1984 about British realist films: "The term 'realism' is used because it is the key term in that discourse mobilized by contemporary critics and film historians alike to validate these films as the most worthy aspects of British film making" ([24], p. 2). Yet, immediately another definition of "realism" surfaces in opposition to the association of realism with quality, as Higson's frames his paper with three quotations. The third, written in 1963 in the Society of Film and TV Arts Journal by an unnamed commenter, defines realism as follows: "Today most people talk about a New Realism—a realistic realism, and that would mostly seem to cover swearing, talking about contraceptives, two people just up to the moment of sexual intercourse and That Long Shot of Our Town from That Hill" ([24], p. 2). This quotation precipitously deflates the grand claims to the artistic and political merit of films validated through realism by pointing to the specific aesthetic, narrative, and cinematographic conventions that are used to convey "realism" to audiences, opening a space of critique between the magic and weight of realist effects and the actual contrivance of their production.

Higson's discussion of realism as an aesthetic contrivance highlights the gap that stubbornly remains in realist forms between the real and the representation of the real; yet it also points toward the relationship between realism and normative systems of social legibility. The corollary to his conclusion suggests that at the far other end of narrative forms that emphasize their status as fiction unfolding within highly constructed story worlds with very different rules and natural conditions from our own, that is, high fantasy, fairy tale, and science fiction storyworlds, including Game of Thrones, reality effects and truth claims may still function because realism is largely a matter of visual and narrative conventions, not access to actually unfolding reality. However, this also implies that the language, structures, and feeling of realism will be highly contextual and historically contingent. Thus, while in 1963 the mention of contraception may have felt shockingly realistic, audience expectations and genre structures have shifted, which says nothing about the actual state of contraceptive use, but quite a lot about the underlying structures of intelligibility within the mainstream media industry over time. Intelligibility thus emerges as a key underlying normative function of the realist mode. That which can be shown on screen and considered real in a given era structures a boundary between sense and nonsense, possibility and impossibility. The unintelligibility of sexual choices outside of heteronormative frameworks forms a central preoccupation of Judith Butler's Gender Trouble, wherein she writes, "The task here is...to redescribe those possibilities that already exist, but which exist within cultural domains designated as culturally unintelligible and impossible" ([25], p. 203). Likewise, realist quality TV like Game of Thrones marks a cultural boundary of controversial but intelligible images, 
beyond which less culturally valued forms, including fan fiction and the fairy tale, may excavate a collective archive of culturally unrealistic and impossible stories and lives.

As a result, the status of realism in Game of Thrones reveals important shifts in the cultural status of $\mathrm{TV}$, the fairy tale, transmedia storytelling, and gendered pleasures within the modern media industry. Thus, in addition to legibility, probability functions as a second critical criterion for evaluating realist claims; in other words, whose pleasures are considered reasonable and probable, and whose pleasures are considered unrealistically improbable? Both fantasy and fairy tales carry strong associations with unreality. This may be partly because, as Maria Nikolajeva argues in "Fairy Tale and Fantasy", the fantasy genre emerged from fairy tales, and though fantasy translated fairy tales from archaic to modernist cosmologies, it still shares some of the fairy tale's underlying tropes and iconography [26]. Yet, in her study of realism in modern fairy tale rewrites, Joosen makes a distinction between theorists who define realism as excluding magic and the supernatural, which would immediately disqualify both fairy tales and fantasy, and those like Jack Zipes who see realism in narratives that utilize metaphor and allegory to reveal historical or contemporary social truths $[5,27,28]$. She thus quotes Bernd Wollenweber's assertion that "fairy tales are not fantastic or unrealistic, on the contrary, they are highly realistic. They represent experiences, they show actual conflicts, they describe private and social relationships" ([5], p. 229). Yet, fairy tales still struggle to attain cultural status as realist, while HBO's Game of Thrones utilizes several specific strategies to distance itself from fantasy's "unrealistic" and feminized fairy tale roots, and align itself with serious realist drama, primary among which is the refusal of "improbable" "happily ever after" narrative closure. The realist mode is repeatedly, though not always, associated with dystopian and cynical portrayals of history, society, and everyday life, often in opposition to genres like romanticism, utopianism, the pastoral, and the hero's journey. Yet the association between realism, quality, graphic content, and negative outcomes also reinforces a gendered binary with narratives like the melodrama and the fairy tale, which are deemed unrealistic, partly because of what Nikolajeva calls "morally fixed" happy or tragic outcomes [26]; she argues that such outcomes lack complexity, the defining characteristic of quality narration highlighted by Mittell $[8,9,29,30]$. The opening contrast between Game of Thrones and Once Upon a Time exemplifies this divergence in value between the quality cable drama, whose dominant register is fantasy, and the unrealistic network melodrama, whose dominant narrative element is the fairy tale. Differences in these programs, therefore, map onto gendered underpinnings of taste culture hierarchies, which theorists Michael Newman and Elana Levine argue mark quality TV as a masculine realm of distinction and regular TV as a feminized space of consumption [4]. In their co-written book, Legitimating Television, they explain that the ascent of quality TV comes with a cost, namely the further intensification of cultural shame and disparagement directed toward populations still associated with "non-quality TV", like Once Upon a Time, namely "children and women", whose desires and media objects remain at the bottom of taste hierarchies ([4], p. 16). Even Geraghty, who championed the study of TV quality, cautioned that the uncritical embrace of quality TV discourse would merely "end[ed] up with a version of the 'difficult', male-orientated, naturalist drama of an earlier television studies" ([7], p. 32).

Fairy tales, especially in the happily-ever-after mode, thus function as the unreasonable feminine other, in contrast to reasonable realist masculine drama. It is no mistake, therefore, that Nikolajeva proposes a gendered narrative of progress from the fairy tale, which she characterizes as overly simplistic, to the more sophisticated fantasy genre [26]. Debra Ferreday underlines this gendered cultural association when she explains that, despite the voluminous and productive history of feminist and queer fantasy literature, most commentators still assume there are no female fantasy writers or fans, and react with amazement when confronted by Game of Thrones' large female fan following ([16], p. 24). Joosen discusses this hidden, gendered criteria of reasonableness or probability within the construction of realism, writing, "When critics use the term 'realism' on the level of content, it can mean both what is 'possible' or what is 'probable'"' ([5], p. 229). Both fairy tales and fantasy violate the criterion of the possible, as both contain magical and/or supernatural elements; yet it is the criterion of the probable that fairy tale happy outcomes appear to violate with their unreasonable feminine optimism. 
Thus, realism functions within Game of Thrones as part of a branding strategy to maintain separation from regular television on the grounds of quality $[10,13]$. While scholars like Thompson and Mittell have discussed a number of characteristics associated with the construction of quality TV, Newman and Levine emphasize that gendered hierarchies and elitism centrally structure judgments about the taste value of television $[4,11]$. As a signatory of quality, realism, particularly as defined by the characteristics of the probable and legible combined with a focus on gruesome subject matter and concomitant repudiation of fairy tale happy endings, thereby adds to the problematic gendered hierarchies that construct quality on contemporary TV. Game of Thrones' claims to quality via realism thus connect to a rejection of feminized "unrealistic" modes of storytelling, and for the fantasy genre that particularly means rejection of its seed-genre the fairy tale, with its "improbable" embrace of positive possible outcomes. Therefore, fan fiction stories that recombine Game of Thrones with fairy tale elements offer fan audiences a glimpse of stories and lives made improbable and unintelligible by the framework of value that underpins quality on contemporary TV.

\section{Feminists, Fans, and Dreams of a Transmedia Utopia}

Although fairy tales have often been associated with women, they have frequently also been characterized as bad for women, especially the "happily-ever-after ending" as popularized by Disney [31]. Although children form the dominant expected modern fairy tale audience, critics like Deborah Ross and Marcia Lieberman argue that romantic fairy tales experienced in childhood continue to affect adult women's expectations about their gender role and their future heterosexual relationships [32-34]. Thus, in particular, the happily-ever-after ending receives criticism as both too dangerously oppressive and too unrealistically positive both for women and for politics [34-38]. Yet, such criticisms needlessly foreclose possibilities for both the personal and political imagination of different futures made possible through utopian storytelling. As a practice of the possible, which structurally undermines any authoritative version of fictional events, fan fiction provides space for unexpected encounters between Game of Thrones' realist-dystopian fantasyscape, and the utopian possibilities for change and alternate futures found within fairy tale conventions. Game of Thrones AUs featuring happily-ever-after endings thus explore productive political and aesthetic hybridities unavailable to either genre form in isolation, facilitated by the non-profit distribution infrastructure of the fan community.

Feminist critiques of the happily-ever-after ending often emphasize either its oppressive tendency toward normativity and closure or its wholehearted embrace of heterosexual bliss. Thus, it is a curious problem that the lives of female fairy tale protagonists seem to always end with marriage, especially in Disney versions, as argued by Stone [31]. Not only does marriage mark the end of the plot, but also quite literally the end of the characters' lives, because the phrase "happily ever after" indicates an unchanging stasis. As a result, a great many feminist reinterpretations of fairy tales attempt to break the narrative closure sealing fairy tale heroines into the forever-stasis of happiness, to allow them to continue growing, changing, and living interesting lives [27,39,40]. Theorist Jack/Judith Halberstam argued that this narrative structure reinforces larger cultural systems of heteronormativity and patriarchy by normalizing one single life path that ends in heterosexual marriage and children, making the many other potential life paths seem abnormal, improbable, and unintelligible [41]. In contrast, he offers the concept of "queer time" to describe all the many alternate ways a lifetime might be structured when the normative ways of organizing time, and narrating it into coherence, are abandoned. Combined with the momentum that propels readers toward the resolution of fictional conflicts and makes those resolutions feel satisfying, feminist critiques of the ever-after ending conclude that such fairy tales are not only powerful because they remove alternate options and storylines, but because they make women's disempowerment feel like pleasure [42]. 
On the contrary, another source of happily-ever-after criticism decries such endings as unrealistically happy. Fairy tales, so one is told, give women unrealistically high expectations of men. They lead women to believe that their inevitable, or compulsory, in Adrienne Rich's terms, future husbands will be loving and kind, and that marital relationships are fulfilling and, above all, happy [43]. This is, apparently, far too much to expect from life, or more specifically, from men who, in this evaluation, are much more likely to be cruel or indifferent. Similar critiques surface in Tania Modleski and Janice Radway's discussions of the romance genre, another offspring of the fairy tale for scholars, including Linda Lee, who argue that the genre primarily functions to transform what they describe as the normative female experience of male cruelty into a sign of love capable of producing happiness [32,44,45]. It is also an idea that Game of Thrones' version of realism nearly specializes in disrupting. This pattern is perhaps most apparent in Sansa Stark's storyline, which begins with a nearly fairy tale structure, as a beautiful and naive young princess arrives in a distant land to marry the prince and live happily ever after. Yet Game of Thrones quickly quashes Sansa's and the audience's expectations with a sharp dose of "realism," as the prince turns out to be a psychopath, incapable of redemption via the storied love of a good woman, and Sansa ends up beaten, humiliated, and rejected. Sansa, perhaps unsurprisingly, becomes a popular heroine of fan fiction fairy tale AUs, since her story directly evokes and then rejects the fairy tale form.

In political terms, the happily-ever-after ending is a form of utopianism, and comes with the same foibles and potentials as many forms of utopian storytelling. Many post-structuralists critique political projects aimed at utopian dreams of a better future largely because, in Michel Foucault's conception, they do not actually do away with power, and for Lee Edelman, they require expensive and cruel sacrifices in symbolic exchange for a more perfect tomorrow, which never arrives [46-49]. As historian and theorist James C. Scott explains, utopian thinking has strong costs because it proposes an unfeasible "end to history" when everything will be perfect, no other challenges or problems will emerge, and further change will be unnecessary-in fairy tale terms, the happy couple fades into the sunset [36-38]. In addition, Scott continues, utopian political projects also tend toward authoritarianism, as individual desires and local circumstances are subsumed within a larger collective agenda-thus the happily-ever-after ending's coercive suppression of alternate life paths.

Yet, at the same time, Scott cautions that some form of utopian thinking may always be necessary for political action, and in the case of fiction, Scott's work could suggest that coercive closure may be necessary for narrative pleasure [36-38]. Without imagining a better, different future, how might people be motivated to act collectively to improve their circumstances? In her book, Cruel Optimism, Lauren Berlant explores this crossroads in her consideration of the same political critique that is often leveled against fairy tale happy endings: when placed within a utopian genre form, oppression can feel like pleasure, and many of our most culturally cherished stories about liberation and happiness actually trap us in a situation that, like patriarchy and capitalism, is actively cruel, exploitative, and limiting [50]. Berlant's attempts to imagine an anti-neo-liberal politics leading to a "better good life" without the promise of a single static definition of political good places her in dialogue with Scott's description of the ultimate political challenge left by the dissolution of many utopian political projects of the 20th century into authoritarianism: how might we imagine and collectively act upon dreams of a better future without instantiating an oppressive and smothering end of history? In other words, is there such a thing as a happy life after happily ever after?

Fairy tale traditions and fan fiction cultures offer key critical alternatives to mass-mediated storytelling in their ability to undermine the coercive inevitability of any one ending; as such, they also open alternative political and narrative uses of utopian storytelling, including "happily ever after." The singularity of utopian endings, which make all other endings illegitimate, only becomes feasible because of the monopoly on storytelling granted to authors via copyright law and cultural authority, from the print era onward [51-53]. There is, indeed, life after happily ever after when the author does not automatically have the last say, and anyone can reopen closed narratives to tell their own version of past and future events. In his landmark article "The Death of the Author", Roland Barthes unpacks 
the cultural and linguistic influences that place texts, not so much as individual works of genius, but as part of a collective history of meaning creation and storytelling [54]. Fairy tales represent an extreme version of this principle, since many derive from a long legacy of oral culture and communal storytelling practice wherein the notion of a "correct" version makes little sense. Yet, Foucault cautions that, even when authors do not or cannot exist, within the present cultural paradigm someone or something must still serve the author-function [55]. For fairy tales, collectors like the brothers Grimm have often served the author-function, but, within the modern mass media, Disney Corporation frequently takes this position and the associated authority through its ability to reach an enormous global audience, and through strategic use of copyright law [56]. Although Stone is suspicious of some oral storytelling versions as well, she and many other theorists often reserve their greatest vitriol for the particular way in which Disney versions of fairy tales dominate the cultural conversation and appear to take characters and stories that were once part of a living tradition and freeze them in time, never to be modified again [31]. Copyright and mass distribution are the tools through which the Disney version of fairy tales becomes inescapable and inevitable—or essential and authoritarian—because it makes all other versions and alternatives illegitimate and unspeakable in public media space (or at least makes a strong attempt) $[56,57]$.

In this sense, the folk history of fairy tales and the rise of modern transmedia storytelling, convergence culture, and fan cultures provide an important alternative to mass media and an important democratizing context for mass-mediated stories. In her examination of the diffuse, multi-authored, and multi-media networks through which fairy tales have always proliferated, Cristina Bacchilega coins the term, "fairy tale web", to describe the vast complexity of interconnected meanings that underlie fairy tales [58]. She argues that although Disney certainly has an outsized affect on public awareness and interpretation of fairy tales, at this point in history it is difficult to remain unaware of at least some of the other parts of the fairy tale web, which include transnational, critical, and amateur retellings. Bacchilega makes the case that audiences can and do have an unpredictable series of encounters with fairy tale media, and they bring all of those experiences to bear on future interaction with and interpretation of fairy tale narrative elements. In other words, every happy ending can only be the beginning of a new story, because within the fairy tale web, no individual story can maintain ultimate authority. Henry Jenkins and Carlos Scolari extend a similar argument to all sorts of transmedia storytelling, which forms an increasingly central part of the modern media industry [59-62]. Because media corporations more and more often disperse story elements across a variety of media, and a variety of media spaces, while inviting fans to participate and add to the story themselves, transmedia storytelling undermines clear distinctions between legitimate and illegitimate authors, or between a canon or core narrative and peripheral fan works $[63,64]$. Judith Fathallah documents Game of Thrones' transmedia deployment of its narrative elements, including explicit calls for fan-created transmedia extensions despite the author's stated disapproval of fan works, a move which thus destabilizes the author's intentions as the chief determinant of narrative cohesion [65]. As a result, Jenkins, Scolari, and Marie-Laure Ryan argue that, for audiences, amateur or fan additions to a transmedia storyworld may be received as equally legitimate to those produced by professionals $[60-62,66]$.

Jenkins has also argued that modern fan cultures who produce transformative works act in continuity to oral, communal storytelling cultures like those that first produced fairy tales [67]. In this way, fan communities and fan fiction are the modern inheritors of a storytelling tradition that predates copyright, in which all people had the authority to add their own version of events to the ongoing story of shared culture. Thus, Mafalda Stasi has argued that fan fiction is a form of "palimpsestic literature", wherein each story is heavily intertextual and its full depth cannot be understood by analyzing the text itself, but necessitates consideration of all the many layers of texts and intertexts which underlie it [68]. Game of Thrones fairy tale AUs perfectly exemplify this principle, as these fan works reconceptualize the HBO show, the books the show is based on, and the fairy tale genre, as well as other fan-specific genre conventions, while the books themselves also draw heavily on numerous layers of fairy tale, alternate history, and fantasy novels, films, and stories as intertexts. Such complexity emphasizes the 
status of authors as communal actors who reorder an existing discursive field; as discussed by scholars like Julie Levin Russo, the politics and aesthetics of fan works must not, therefore, be considered in terms of the qualities of the text alone, but in contrast to the entire amateur and professional cultural milieu, as fan authors' and artists' expressions are frequently only made implicitly via their subtle departures from other versions and narrative norms [69-72].

Fan fiction also maintains a strong element of utopian thinking, since, especially in the internet era, it allows audiences space to circulate their most expansive dreams with no editorial controls [73]. As I have argued elsewhere, the free or at-cost circulation of internet fan fiction ensures that, although trends and taste communities form, fan production of transformative works, including fan fiction, may continue far in excess of demand, meaning that neither the legal nor economic realities of the media industry limit how much fan material can be published, and how much cultural and narrative experimentation can occur [70]. As a result, fan authors have the freedom to write and circulate material that professionals shy away from, a phenomena described by fan author Ellen Fremedon as the "Id vortex", wherein fans may more openly embrace material considered naive, utopian, and taboo than the industry [74]. Similarly, Elizabeth Woledge especially calls sexual fan fiction an "intimatopia", wherein unrealistic perfection and seamless intimacy often become the norm [75]. While her discussion does not take into account the many genres of fan writing dedicated to dystopia, gruesome subject matter, and unhappiness, the utopian urge certainly still forms a strong tradition in fan writing communities, and the open space of fan fiction distribution provides for dialogue between all these possible versions of characters' lives [71,76-78]. This allows, to some extent, for fan utopias to enjoy the best of both worlds - they benefit from utopian storytelling's ability to point toward a better future, which can motivate the desire for change, while not foreclosing the possibility for critique and revision, since no one utopia ever maintains authority. As a result, Game of Thrones fairy tale AUs offer a unique form of cultural and narrative experimentation made possible by combining utopian, fairy tale, and fantasy genres within the context of amateur, fan distribution networks.

\section{Game of Thrones Meets a Fairy Tale Ending: the Fairy Tale AU}

Fan fiction stories that combine fairy tale narratives, storyworlds, and tropes with Game of Thrones characters, situations, and settings make that which is impossible on Games of Thrones possible: namely, the happily-ever-after ending. In particular, the fairy tale AU, or alternate universe, genre can allow for a subtle form of critique by constructing beautiful images of future happiness and implicating Game of Thrones, and dominant structures of representation more broadly, in their refusal to allow the realization of this pleasurable and desirable end. In this manner, it is sometimes the very unrealisticness of the happily-ever-after ending that makes it political, questioning the institutions and systems that prevent certain kinds of relationships from being represented, and certain lives from being lived, marking them as improbable and consigning them to illegibility. Thus, despite their perhaps unrealistic utopian urge, some fairy tale AUs based on Game of Thrones may have more in common with Halberstam's concept of queer time than expected, because they detail all the potential paths to good lives that Game of Thrones, quality TV tropes, and the constraints of the dominant mass media suppress as frivolous, illegible, and impossible. A series of case studies will be examined, based on "The Princess and the Frog", "Cinderella", "Beauty and the Beast", and "Bluebeard", published on the "Archive of Our Own" non-profit fan fiction repository [79-81]. Although these stories represent only a drop of the flood of available fan works taken from only one central archive, they still begin to suggest the range of thought experiments possible when the Game of Thrones storyworld collides with the fairy tale, and the way in which fan spaces set all these visions of the better good life into dialogue.

First, "The Princess and the Direwolf" by WelshCakes68 borrows from the tale of "The Princess and the Frog", as well as "Little Red Riding Hood", to make impossible lesbian desires between Game of Thrones characters manifest via magic [82]. The story breaks with realism, both in terms of possibility and plausibility, and yet still addresses real feelings and politics on a metaphorical register. At the opening of the story, Margaery Tyrell slips out of a stuffy ball, away from the scrutiny of 
her grandmother, to sit alone in a garden, near a pond. There she is approached by an enormous wolf, but her initial fear quickly gives way to tenderness when the wolf nuzzles her hand, asking for affection. After snuggling with and feeding the wolf, Margaery tells it that despite her family's pressure, she does not want a husband, and then recounts the legend of the princess who kissed a frog, next to the very pond where they sit; the frog turned into a handsome prince, Margaery says, and they lived happily ever after. Margaery finishes the story with an impossible wish: "If I kiss a wolf instead of a frog, what are my chances that you might turn into a beautiful princess instead?" Setting aside doubt, she leans in to kiss the wolf's snout, and luckily magic intervenes; the wolf does indeed become a princess, transforming into Sansa Stark.

The grandmother reference and the wolf connect to "Little Red Riding Hood", while the story-within-a-story connects to "The Princess and the Frog", both of which fall under the larger category of fairy tales featuring animal transformations. Such "transbiology" stories carry latent queer possibilities, according to Pauline Greenhill, as they construct potential animal-human relationships and subjectivities that push the boundaries of normative sexual imagination, and offer fertile ground for building LGBTQIA ${ }^{2}$ narratives [83]. However, this rich symbolic source of alternate sexual storytelling is foreclosed in the Game of Thrones version of realism, not because of the impossible feat of a human transforming into a wolf, but because of the implausible possibility of lesbian desire and relationships in even a fantastic version of the Middle Ages. In the historically-inflected storyworld of Game of Thrones, patriarchy severely limits the mobility and social power of women, to the extent that they often have little choice but to marry men for survival. Princesses, in particular, have little control over their romantic destiny, as they must marry to forge political alliances. Margaery's and Sansa's character paths are both foreclosed by these principles, as Margaery becomes the serial widow of three (would be) kings and princes, and after her rejection by her betrothed psychopathic prince, Sansa is ruthlessly pursued by others who would like to solidify their claim to the throne or family alliances by marrying into her royal line and the territory her husband inherits. Erotic relationships between men exist in Game of Thrones, but erotic relationships between women are limited to two female prostitutes performing together for the pleasure of their paying male customers [16].

Without access to their own funds, space, and legal status, it is indeed logically difficult for women in Game of Thrones and in actual medieval Europe to form same-sex relationships, as noted by historian of gay identity John D'Emilio in his landmark work on the emancipatory effect of capitalist wage labor for many gay and lesbian people [84]. However, difficult and impossible are not the same, as attested by the work of historians who excavate early lesbian history like Carol Smith Rosenberg, Valerie Traub, Judith Bennett, and Ann Cvetkovich [85-88]. Forgetting that such women existed reinforces a violently heteronormative erasure of real history. Public articulation of the wish for a same-sex partner still remains contentious in modern media, making this story not only relevant to the past, but also the lived reality of contemporary audiences [89]. The impossible wish that comes true in "The Princess and the Direwolf" is a kind of utopian storytelling that both names the injustice and limitations that constrain action and imagination, and seeks to imagine a possible future beyond them. It attempts to make impossible desires possible, first by articulating them into legibility, then by making them manifest. The unrealistic and unrealizable space between the wish and the appearance of the princess is the space of desire, and the engine of change.

Secondly, several retellings drawn from "Cinderella" and "Beauty and the Beast" utilize the fairy tale framework's nearly irresistible momentum toward a happy ending in order to make their culturally unrealistic couples seem inevitable and right for each other [90]. The Cinderella-based story, "A waltz among the cinders", by Empress Irony pairs Sansa Stark with Stannis Baratheon, a relationship made improbable by the couple's large age gap, disparate personalities, and lack of

2 Lesbian, Gay, Bisexual, Trans, Queer/Questioning, Intersex, and Allies. 
meaningful interaction in the source text $[91] .^{3}$ Interestingly, the authors' notes state that "A waltz among the cinders" draws primarily from the Moacube graphic novel game version of the Cinderella story, titled "Cinders" [93]. This underscores its unique situatedness within Bacchilega's fairy tale web as an intertext, not primarily with the Disney Cinderella, but between a transmedia feminist revision and Game of Thrones [58]. Empress Irony's inspiration by Moacube's version, which gives the player a trophy whenever their choices open a non-normative story path, becomes apparent in Sansa's representation as a sexually aggressive, active, and self-possessed heroine; she rejects the narcissistic prince once she arrives at the ball and instead dances the last dance with her kind but stoic fairy protector, as Stannis takes the place of the fairy godmother in this retelling [91]. However, unlike the computer graphic novel, which offers over 300 different possible endings, "A waltz among the cinders" can only end in happily-ever-after for Sansa and Stannis, a narrative structure whose built-in satisfactions may to some extent displace audiences' surprise and potential resistance to their romance. In a way, the very strangeness of Stannis as an unlikely prince charming underscores Sansa's agency as a feminist revision of Cinderella. Whether the audience understands her motivations or not, Sansa actively and eagerly chooses Stannis, and the narrative structure legitimates her as a choosing agent. The last line of the story, reproduced in the title of this article, reinforces the inevitability of this improbable couple's happiness: "And they all lived happily ever after. Obviously" [91]. That "obviously" performs a tricky function of simultaneous closure and disruption as this outcome for Sansa and Stannis is anything but obvious, and at the same time that line, the fairy tale structure, and readers' willingness to believe, can make it so.

Also based on Cinderella, "cedar + gold" by Atlantisairlock again utilizes the near certainty that this tale must end with a happily-ever-after romance to position the union of its same-sex pair as good, right, and inevitable [94]. Sansa again plays Cinderella, and Margaery plays the princess she falls in love with at the ball. Unlike "The Princess and the Direwolf" which makes lesbian desire and relationships a utopian dream within the frame of the narrative, "cedar + gold" takes the opposite tack, making princesses who marry each other just as much part of the fabric of the fairy tale universe as mice who turn into horses, or direwolves who turn into horses, in this case. Yet, the story functions similarly because of the gap between its utopian storyworld and the world portrayed on the TV series. Class difference still functions as a damaging form of social hierarchy in "cedar + gold", but the author sets aside the patriarchal and heteronormative conditions of the source text to imagine a Margaery completely unburdened from the necessity of securing a royal husband, allowed to take on her own political authority, roam the city unchaperoned, and seek the hand of anyone she loves, including a lady. The author explicitly states the utopian wish, which remains utopian to this day, that motivates the storyworld in the author's notes, writing, "In this AU, nobody really cares that Margaery's lover is female" [94]. The ability to articulate a vision of a world in which desire between women goes completely unremarked may seem as unrealistic as fairy godmothers with excellent fashion sense; yet that very comparison provides the story its underlying real political and emotional resonance.

In addition, "Beauty and the Beast" provides the framework within which another unlikely couple, by modern media and cultural standards, comes to appear perfectly suited for a happily ever after. The "Beauty and the Beast" storyline offers not only the happily-ever-after ending but also a curse as tools to reinforce the couple's status as legitimate; if only true love can break the story's curse, then breaking it magically reinforces the strength of the couple's bond. Imagineagreatadventure's

3 For comparison, of the couples discussed here, there are currently 131 stories featuring Sansa and Stannis on the Archive of Our Own, while there are 626 stories about a relationship between Sansa and Margaery, and 1747 stories about Brienne and Jaime. Thus, even in fan circles, the Stannis/Sansa relationship seems relatively unlikely. Critically, the Archive of Our Own is only one among many archives and social networks where fan fiction is published and distributed, so these numbers are only suggestive, not definitive [92]. 
"Beauty and the Beast" pairs Game of Thrones characters Brienne of Tarth and Jaime Lannister [95]. ${ }^{4}$ While Jaime's character slides almost seamlessly into the role of Beast, since both begin their tales as vain, wealthy, and beautiful men whose arrogance brings about a devastating change in their appearance and the beginning of a redemption arc. On the contrary, while Imagineagreatadventure still calls Brienne "Beauty" within the story, she makes clear that the nickname is a cruel joke, as Brienne maintains her appearance from the series, wherein she is explicitly called ugly. Brienne's masculine appearance and behavior lend themselves to interpretation as signifiers of lesbianism, but perhaps the more challenging characterization for dominant beauty standards is to propose a union between an enormously tall, broad-shouldered, muscle-bound women seen as ugly by her contemporaries, and an attractive, high-status man.

This is the problematic also exposed in the runaway success of transnational adaptations of $Y_{0}$ Soy Betty la Fea/Ugly Betty, which proposed to break the mold of beauty culture by following the life of an ugly woman working in the fashion industry. Yet most versions of the show notoriously cast very beautiful actresses, only made "ugly" with makeup and accessories, which the makeover-inspired narrative required must be removed before her happily-ever-after romance with her boss could come to its culmination $[97,98]$. Imagineagreatadventure constructs an opposing utopian fantasy by proposing that Brienne can find her happy ending without a makeover, and without giving up her masculine behaviors or self-presentation; this conclusion may seem all the more improbable with a male rather than a female partner, wherein Brienne may be read as straightforwardly butch within a butch-femme dynamic. Thus, once again, like the Cinderella-based stories, Imagineagreatadventure utilizes "Beauty and the Beast's" built-in momentum toward utopian plentitude and closure to set up the union between Brienne and Jamie as acceptable and satisfying. In this manner, the happily-ever-after ending and its utopian storytelling structure can perform a perhaps surprisingly progressive political function.

Finally, "The Chamber Below the Dreadfort" by Phoenixflame88 places Game of Thrones characters within Angela Carter's "The Bloody Chamber", a feminist rewrite of the Bluebeard tale, in order to draw a parallel feminist critique $[40,99]$. Phoenixflame 88 closely follows Carter's version, placing Sansa Stark as the protagonist, who, like Carter's heroine, tells the story from her point of view, although in a third-person rather than first-person perspective. Ramsay Bolton, a serial murderer and torturer, easily takes on the role of Bluebeard, and his captive Theon Greyjoy/Reek becomes Carter's blind piano tuner. "The Chamber Below the Dreadfort" utilizes Carter's feminist fairy tale revision to similarly critique Game of Thrones for the way it presents Sansa as a weak, innocent victim, unable to control or express her own sexuality. Both stories follow the life of a young woman who has agreed to marry an older man with a dark reputation, largely for social and financial stability for herself and her family. This also neatly describes the season five Game of Thrones storyline about Sansa's marriage to Ramsey. Carter and Phoenixflame88 depart from other tellings, including Game of Thrones, when their heroine begins to fantasize about the sexual aspects of her coming marriage, and later enjoys her sexual encounters with her husband, a theme that Phoenixflame88 especially develops. However, following from Bluebeard, the heroine soon discovers a hidden room containing the dead bodies of her new husband's previous wives, and in both the TV series and "The Chamber Below the Dreadfort" Theon's/Reek's restrained, mutilated body serves this purpose, as well as the dead bodies of Ramsay's other victims. However, in the TV series, these events are reversed, with Sansa encountering the tortured Theon/Reek before the consummation of her marriage, which then does not lead to the discovery of her own sexual self, but instead culminates in a grotesque rape that Theon/Reek witnesses as a further form of torture. Finally all versions then end in the heroine's escape, although in most traditional retellings and the TV series, it is men, the brothers of Bluebeard's victims in one case and an army in the other, who free the heroine, while in the Carter and Phoenixflame88 version it is the heroine's mother who performs the

4 "Heartsick" by Lady Blade WarAngel offers a similar story structure wherein the breaking of a curse reinforces the rightness of the Brienne/Jamie relationship. However, while clearly inspired by fairy tale tropes, Lady Blade WarAngel constructs an original storyline that does not strictly reproduce any single fairy tale [96]. 
role of hero and protector, killing Bluebeard/Ramsay to save her daughter. In all versions, perhaps except the TV show, the heroine goes on to live happily ever after, although the nature of that happiness varies; as for the traditional version she remarries, while in Carter's version the heroine, piano tuner, and mother form an intergenerational household, and in Phoenixflame88's story Sansa takes authority over her family seat in Winterfell alone, only later to be joined by Theon.

"The Chamber Below the Dreadfort" expresses utopian critiques of Game of Thrones in at least three ways. First, simply by so easily transposing the TV characters and plots into the Bluebeard myth and applying Carter's rewrite in so straightforward a fashion, Phoenixflame88's version indicts the source text on the same grounds, as a narrative that disempowers and victimizes women, robbing them of mature sexual agency ([100], pp. 10-12). The fact demonstrated by Phoenixflame88 that Game of Thrones basically repeats the Bluebeard myth speaks for itself, in a sense. Secondly, Phoenixflame88's repetition from Carter of Sansa's sexual awakening and growing maturity, culminating in her utopian achievement of full independent adulthood responsibilities as the sole ruler of Winterfell at the story's happily-ever-after ending, also implicitly criticizes the character's limited and disempowering storylines in the official show, in which she is passed between three successive sadistic or unwanted husbands. Finally, while Sansa's mother Catelyn Stark rescues her at the end of Phoenixflame88's story, like the mother figure in Carter's rewrite, in the Game of Thrones TV series Catelyn is long dead by the time Sansa marries Ramsey, leaving her alone and specifically without connections to other women. Although Brienne maintains loyalty to Catelyn even after her death and tries to protect Sansa, this is not possible within the Game of Thrones storyworld. Few women in Game of Thrones maintain significant emotional ties to other women or have the resources or status to protect other women, and the powerful bond between Catelyn and Sansa in "The Chamber Below the Dreadfort" offers another utopian vision of an alternate future wherein female characters do not become isolated victims, but instead act collectively in mutual solidarity.

In sum, while fan fiction stories come in numerous genres, ideologies, and formats, these examples demonstrated that combining Game of Thrones with fairy tale elements can produce culturally potent utopian visions. In "The Princess and the Direwolf", a utopian wish reveals the painful constraints of the Game of Thrones story world and questions our ability to imagine the possibility of pre-modern (and post-modern) lesbian lives. By situating culturally unlikely couples as inevitably bound for a happily-ever-after ending, fairy tale AUs can question sex and gender hierarchies, and imagine a world in which women are agents of their own desires, princesses can marry each other, and a butch woman may love a beautiful beast of a man. Positioning these couples' happiness at the resolution of a stereotypical fairy tale romance challenges the cultural standards that made them seem like unlikely pairs, and structurally primes the audience to experience their union as pleasurable and meant to be. While the content of "The Chamber Below the Dreadfort" may at first appear rather dark, it nonetheless culminates in a happily-ever-after ending that questions the character's fate in the TV series, while constructing an alternate future in which women are able to exert political power, reach sexual maturity, and maintain bonds of solidarity with each other. All of these utopian dreams strongly critique the world of the series, the boundaries of quality TV realism, and, to a certain extent, contemporary reality as well, by the injustice of their unattainability, and for the institutional conditions that make these visions still seem unrealistic.

\section{Conclusions}

To conclude, fan fiction AUs that combine Game of Thrones characters and settings with fairy tale elements construct a dialogue between realism and wonder. In so doing, they may uncover poetic and political possibilities unavailable to either genre in isolation. While realism functions within HBO's branding strategy as a signatory of "quality TV", often at the expense of deriding feminine genres, including melodrama and the fairy tale, reinserting these feminine pleasures and plots into Game of Thrones opens new horizons of representation, and points out stifling erasures within the series' realist storyworld. As such, Game of Thrones-based fairy tale AU fan fiction demonstrates some surprisingly 
radical uses for the frequently criticized happily-ever-after ending, namely, for its ability to point out the media and social institutions that still make some couples' success and some people's life course seem painfully unrealistic. Thus while "happily ever after" may become a cloying form of constraint, in the hands of fan fiction writers, circulating their works within a communal storytelling culture that normalizes dialogue between multiple versions, fairy tale endings may magically transform the limitations of utopian thought, and construct political and erotic dreams worth believing in.

Acknowledgments: This article results in part from support provided by the Social Sciences and Humanities Research Council of Canada Partnership Development Grant \#890-2013-17, "Fairy Tale Cultures and Media Today". Thanks to my partnership colleagues Pauline Greenhill, Jill Rudy, Sadhana Naithani, Martin Lovelace, Steven Kohm, Catherine Tosenberger, Cristina Bacchilega, Jack Zipes, Naomi Hamer, Kendra Magnus-Johnston, and Lauren Bosc, as well as my research assistant Nina Köll, who have taught me a great deal about enchantment and wonder. Thanks also to the many fans who dedicate their time and passion to reimagining the characters of Game of Thrones through a fairy tale lens. Your work is inspiring and I thoroughly enjoyed spending many pleasant afternoons in your literary company.

Conflicts of Interest: The author declares no conflict of interest.

\section{References}

1. Game of Thrones. Directed by David Benioff, Alan Taylor and Daniel Brett Weiss. Written by David Benioff, George R. R. Martin and Daniel Brett Weiss. Home Box Office (HBO), 17 April 2011.

2. Once Upon a Time. Directed by Romeo Tirone and Ralph Hemecker. Written by Edward Kitsis and Adam Horowitz. ABC Studios, 23 October 2011.

3. “'Operation Mongoose.' 421/422." Once Upon a Time. Directed by Romeo Tirone and Ralph Hemecker. Written by Edward Kitsis and Adam Horowitz. ABC Studios, 10 May 2015.

4. Michael Newman, and Elana Levine. Legitimating Television: Media Convergence and Cultural Status. New York: Routledge, 2011.

5. Vanessa Joosen. "Disenchanting the fairy tale: Retellings of 'Snow White' between magic and realism." Marvels \& Tales 21 (2007): 228-39.

6. Kim Akass, and Janet McCabe. "Sex, swearing and respectability: Courting controversy, HBO's original programming and producing quality TV." In Contemporary Quality TV: American Television and Beyond (Reading Contemporary Television). London: I. B. Tauris, 2007, pp. 62-76.

7. Christine Geraghty. "Aesthetics and quality in popular television drama." International Journal of Cultural Studies 6 (2003): 25-45. [CrossRef]

8. Anikó Imre. "Gender and quality television: A transcultural feminist project." Feminist Media Studies 9 (2009): 391-407. [CrossRef]

9. Michael Kackman. "Quality Television, Melodrama, and Cultural Complexity." Flow, 31 October 2008. Available online: http://flowtv.org/?p \protect\$relax \protect\\begingroup1 \endgroup \@@over4\$\$2101\# printview (accessed on 15 May 2009).

10. Marc Leverette, Brian L. Ott, and Cara Louise Buckley, eds. It's Not TV: Watching HBO in the Post-Television Era. New York: Routledge, 2008.

11. Jason Mittell. “Narrative complexity in contemporary American television.” The Velvet Light Trap 58 (2006): 29-40. [CrossRef]

12. Robin Nelson. "'Quality Television': 'The Sopranos is the best television drama ever ... in my humble opinion ... '." Critical Studies in Television: The International Journal of Television Studies 1 (2006): 58-71. [CrossRef]

13. Tobias Steiner. "Steering the author discourse: The construction of authorship in quality TV, and the case of Game of Thrones." Series-International Journal of TV Serial Narratives 1 (2015): 181-92.

14. Raymond Williams. Television: Technology and Cultural Form. London: Fontana, 1974.

15. Robert J. Thompson. Television's Second Golden Age: From Hill Street Blues to ER. New York: Continuum, 1996.

16. Debra Ferreday. “Game of Thrones, rape culture and feminist fandom." Australian Feminist Studies 30 (2015): 21-36. [CrossRef]

17. Stefan Morrone. "How Game of Thrones Teaches Us about the Syrian Refugee Crisis." Institute for Ethics and Emerging Technologies, 3 December 2015. Available online: http://ieet.org/index.php/IEET/more/ Morrone20151203 (accessed on 28 March 2016). 
18. Jamie Seidel. "The Real Human History behind Game of Thrones." News Corp Australia, 9 April 2014. Available online: http:/ /www.news.com.au/world/the-real-human-history-behind-game-of-thrones / story-fndir2ev-1226879236503 (accessed on 28 March 2016).

19. Matthew Taunton. "Why Game of Thrones is More than Fantasy." New Humanist, 3 June 2015. Available online: https://newhumanist.org.uk/articles/4883/why-game-of-thrones-is-more-than-fantasy (accessed on 28 March 2016).

20. Jamie Adair. "History behind Game of Thrones." Available online: http://history-behind-game-of-thrones. com/george-rr-martin/grrm-rolling-stone (accessed on 28 March 2016).

21. Alex Gendler. "The Wars that Inspired Game of Thrones." TedEd, 11 May 2015. Available online: https: / /www.youtube.com/watch?v=VjO55pKuBo4 (accessed on 28 March 2016).

22. Mikal Gilmore. “George R.R. Martin: The Rolling Stone Interview.” Rolling Stone Magazine, 23 April 2014. Available online: http:/ / www.rollingstone.com/tv/news/george-r-r-martin-the-rolling-stone-interview20140423 (accessed on 28 March 2016).

23. Luc Herman. Concepts of Realism. St. Marys: Camden House, 1997.

24. Andrew Higson. "Space, place, spectacle." Screen 25 (1984): 2-21. [CrossRef]

25. Judith Butler. Gender Trouble: Feminism and the Subversion of Identity. New York: Routledge, 2006.

26. Maria Nikolajeva. "Fairy tale and fantasy: From archaic to postmodern." Marvels $\mathcal{E}$ Tales 17 (2003): 138-56.

27. Jack Zipes. Don't Bet on the Prince: Contemporary Feminist Fairy Tales in North America and England. New York: Methuen, 1986.

28. Jack Zipes. Why Fairy Tales Stick: The Evolution and Relevance of a Genre. New York: Routledge, 2006.

29. Lynne Joyrich. "All that television allows: TV melodrama, postmodernism and consumer culture." Camera Obscura 6 (1988): 128-53. [CrossRef]

30. Lynne Joyrich. Re-Viewing Reception: Television, Gender, and Postmodern Culture. Bloomington: Indiana University Press, 1996.

31. Kay Stone. "Things Walt Disney never told us." The Journal of American Folklore 88 (1975): 42-50. [CrossRef]

32. Linda J. Lee. "Guilty pleasures: Reading romance novels as reworked fairy tales." Marvels $\mathcal{E}$ Tales 22 (2008): 52-66.

33. Marcia R. Lieberman. "Some day my prince will come': Female acculturation through the fairy tale." College English 34 (1972): 383-95. [CrossRef]

34. Deborah Ross. "Escape from wonderland: Disney and the female imagination." Marvels $\mathcal{E}$ Tales 18 (2004): 53-66. [CrossRef]

35. Karlyn Crowley, and John Pennington. "Feminist frauds on the fairies?: Didacticism and liberation in recent retellings of "Cinderella'." Marvels E Tales 24 (2010): 297-313.

36. James C. Scott. Domination and the Arts of Resistance: Hidden Transcripts. New Haven: Yale University Press, 1990.

37. James C. Scott. Seeing Like a State: How Certain Schemes to Improve the Human Condition Have Failed. New Haven: Yale University Press, 1998.

38. James C. Scott. Weapons of the Weak: Everyday Forms of Peasant Resistance. New Haven: Yale University Press, 1985.

39. Cristina Bacchilega. Postmodern Fairy Tales: Gender and Narrative Strategies. Philadelphia: University of Pennsylvania Press, 2010.

40. Angela Carter. "The bloody chamber." In The Bloody Chamber and Other Stories. New York: Penguin Books, 1990, pp. 7-40.

41. Jack/Judith Halberstam. In a Queer Time and Place: Transgender Bodies, Subcultural Lives. New York: NYU Press, 2005.

42. Deborah O'Keefe. Good Girl Messages: How Young Women Were Misled by Their Favorite Books. New York: Bloomsbury Academic, 2001.

43. Adrienne Rich. "Compulsory heterosexuality and lesbian existence." Signs 5 (1980): 631-60. [CrossRef]

44. Tania Modleski. Loving With a Vengeance: Mass Produced Fantasies for Women, 2nd ed. New York: Routledge, 2007.

45. Janice Radway. Reading the Romance: Women, Patriarchy, and Popular Literature. Chapel Hill: The University of North Carolina Press, 1991.

46. Judith Butler. Frames of War: When Is Life Grievable? Brooklyn: Verso, 2016.

47. Lee Edelman. No Future: Queer Theory and the Death Drive. Durham: Duke University Press, 2004.

48. Michel Foucault. The History of Sexuality, Vol. 1: An Introduction. New York: Vintage, 1990.

49. Jack/Judith Halberstam. The Queer Art of Failure. Durham: Duke University Press Books, 2011. 
50. Lauren Berlant. Cruel Optimism. Durham: Duke University Press Books, 2011.

51. Michele Boldrin, and David K. Levine. Against Intellectual Monopoly. Cambridge: Cambridge University Press, 2008.

52. Rebecca Tushnet. "Copyright as a model for free speech law: What copyright has in common with anti-pornography laws, campaign finance reform, and telecommunications regulation." Boston College Law Review 42 (2000): 1-79.

53. Rebecca Tushnet. "Legal fictions: Copyright, fan fiction, and a new common law." Loyola of Los Angeles Entertainment Law Journal 17 (1996): 651-86.

54. Roland Barthes. "The death of the author." In Image/Music/Text. New York: Hill and Wang, 1977, pp. $142-47$.

55. Michel Foucault. "What is an author?" In Aesthetics, Method, and Epistemology. Edited by James Faubion. New York: The New Press, 1998.

56. Lawrence Lessig. “The creative commons.” Montana Law Review 65 (2004): 1-14.

57. Jessica Litman. "Mickey Mouse emeritus: Character protection and the public domain." University of Miami Entertainment \& Sports Law Review 11 (1993): 429-35.

58. Cristina Bacchilega. "Introduction: The fairy-tale web." In Fairy Tales Transformed?: Twenty-First Century Adaptations and the Politics of Wonder. Detroit: Wayne State University Press, 2013, pp. 1-30.

59. Henry Jenkins. Convergence Culture: Where Old and New Media Collide. New York: NYU Press, 2008.

60. Henry Jenkins. "Transmedia Storytelling 101." 2007. Available online: http://henryjenkins.org/2007/03/ transmedia_storytelling_101.html (accessed on 10 January 2016).

61. Henry Jenkins. “Transmedia 202: Further Reflections." 2011. Available online: http://henryjenkins.org/ 2011/08/defining_transmedia_further_re.html (accessed on 10 January 2016).

62. Carlos Scolari. "Lostology: Transmedia storytelling and expansion/compression strategies." Semiotica 195 (2013): 45-68. [CrossRef]

63. Anne Kustritz. "Seriality and transmediality in the fan multiverse: Flexible and multiple narrative structures in fan fiction, art, and vids." TV/Series 6 (2014): 225-61. [CrossRef]

64. Maria Lindgren Leavenworth. "Transmedial Texts and Serialized Narratives." Transformative Works and Cultures, 2011. [CrossRef]

65. Judith Fathallah. "Statements and silence: Fanfic paratexts for ASOIF/Game of Thrones." Continuum: Journal of Media E Cultural Studies 30 (2016): 75-88.

66. Marie-Laure Ryan. “Transmedial storytelling and transfictionality." Poetics Today 34 (2013): 361-88. [CrossRef]

67. Henry Jenkins. Textual Poachers: Television Fans and Participatory Culture. New York: Routledge, 1992.

68. Mafalda Stasi. "The toy soldiers from leeds: The slash palimpsest." In Fan Fiction and Fan Communities in the Age of the Internet: New Essays. Edited by Karen Hellekson and Kristina Busse. Jefferson: McFarland and Company, 2006, pp. 115-33.

69. Karen Hellekson, and Kristina Busse. "Introduction: Work in progress." In Fan Fiction and Fan Communities in the Age of the Internet: New Essays. Edited by Karen Hellekson and Kristina Busse. Jefferson: McFarland and Company, 2006, pp. 5-32.

70. Anne Kustritz. "Slashing the romance narrative." The Journal of American Culture 6 (2003): 371-84. [CrossRef]

71. Louisa Stein, and Kristina Busse. "Limit play: Fan authorship between source text, intertext, and context." Popular Communication 7 (2009): 192-207. [CrossRef]

72. Julie Levin Russo. “User-Penetrated content: Fan video in the age of convergence." Cinema Journal 48 (2009): 125-30. [CrossRef]

73. Amalia Ziv. Explicit Utopias: Rewriting the Sexual in Women's Pornography. Albany: SUNY Press, 2015.

74. Ellen Fremedon. "Id Vortex." Available online: http://fanlore.org/wiki/Id_Vortex (accessed on 6 May 2016).

75. Elizabeth Woledge. "Intimatopia: Genre intersections between slash and the mainstream." In Fan Fiction and Fan Communities in the Age of the Internet: New Essays. Edited by Karen Hellekson and Kristina Busse. Jefferson: McFarland and Company, 2006, pp. 97-114.

76. Jenny Alexander. "Tortured heroes: The story of ouch! Fan fiction and sadomasochism." In Sex, Violence and the Body. London: Palgrave Macmillan, 2008, pp. 119-36.

77. Anne Kustritz. "Painful pleasures: Sacrifice, consent, and the resignification of BDSM symbolism in The Story of $O$ and The Story of Obi." Transformative Works and Cultures, 2008. [CrossRef]

78. Sarah Fiona Winters. "Vidding and the perversity of critical pleasure: Sex, violence, and voyeurism in 'Closer' and 'On the Prowl'." Transformative Works and Cultures, 2012. [CrossRef] 
79. Francesca Coppa. "An archive of our own: Fan fiction writers unite! " In Fic: Why Fanfiction Is Taking Over the World. Edited by Anne Jameson. Dallas: Smart Pop, 2013, pp. 274-80.

80. Alexis Lothian. "An archive of one's own: Subcultural creativity and the politics of conservation." Transformative Works and Cultures, 2011. [CrossRef]

81. Alexis Lothian. "Archival anarchies: Online fandom, subcultural conservation, and the transformative work of digital ephemera." International Journal of Cultural Studies 16 (2013): 541-56. [CrossRef]

82. WelshCakes68. "Femslash February 2015 Challenge: Chapter 27: Fairy Tale." 28 February 2015. Available online: http://archiveofourown.org/works/3273269/chapters/7550171 (accessed on 25 March 2016).

83. Pauline Greenhill. "Wanting (to be) animal: Fairy-Tale transbiology in the story-teller." Feral Feminisms 2 (2014): 29-45.

84. John D'Emilio. "Capitalism and gay identity." In Powers of Desire: The Politics of Sexuality. Edited by Ann Snitow, Christine Stansell and Sharan Thompson. New York: Monthly Review Press, 1983.

85. Judith Bennett. "'Lesbian-Like' and the social history of lesbianisms." Journal of the History of Sexuality 9 (2000): 1-24.

86. Ann Cvetkovich. An Archive of Feelings: Trauma, Sexuality, and Lesbian Public Cultures. Durham: Duke University Press Books, 2003.

87. Carroll Smith-Rosenberg. "The female world of love and ritual: Relations between women in nineteenth-century america." Signs 1 (1975): 1-29. [CrossRef]

88. Valerie Traub. The Renaissance of Lesbianism in Early Modern England. Cambridge: Cambridge University Press, 2002.

89. Gay \& Lesbian Alliance against Defamation. “GLAAD—Where We Are on TV Report-2015." Available online: http:/ / www.glaad.org/whereweareontv15 (accessed on 1 April 2016).

90. Anne Kustritz. "Fan fiction." In Routledge Companion to Fairy Tale Cultures and Media. Edited by Pauline Greenhill, Jill Terry Rudy and Naomi Hamer. New York: Routledge, 2016, forthcoming.

91. Empress_Irony. "A Waltz among the Cinders." 7 March 2016. Available online: http:/ /archiveofourown. org/works/6186253 (accessed on 25 March 2016).

92. “Achieve of Our Own." Available online: http://archiveofourown.org (accessed on 30 March 2016).

93. MoaCube. "Cinders." 2012. Available online: http://moacube.com/games/cinders (accessed on 20 March 2016).

94. Atlantisairlock. “Cedar + Gold.” 16 September 2014. Available online: http:/ /archiveofourown.org/works / 2314460 (accessed on 25 March 2016).

95. Imagineagreatadventure. "Beauty and the Beast." 12 August 2015. Available online: http:/ /archiveofourown. org/works /4077127?view_full_work=true (accessed on 25 March 2016).

96. Lady_Blade_WarAngel. “Heartsick.” 6 June 2014. Available online: http:/ / archiveofourown.org/works / 1747424 (accessed on 25 March 2016).

97. Madeleine Shufeldt Esch. "Rearticulating ugliness, Repurposing content: Ugly betty finds the beauty in ugly." Journal of Communication Inquiry 34 (2009): 168-83. [CrossRef]

98. Yeidy M. Rivero. "The performance and reception of televisual 'Ugliness' in Yo Soy Betty la Fea." Feminist Media Studies 3 (2003): 65-81. [CrossRef]

99. Phoenixflame88. "The Chamber below the Dreadfort." 21 May 2013. Available online: http:/ /archiveofourown. org/works/812308?view_full_work=true (accessed on 25 March 2016).

100. Patricia Duncker. "Re-Imagining the fairy tales: Angela Carter's bloody chambers." Literature and History 10 (1984): 3-14.

(C) 2016 by the author; licensee MDPI, Basel, Switzerland. This article is an open access article distributed under the terms and conditions of the Creative Commons Attribution (CC-BY) license (http:/ / creativecommons.org/licenses/by/4.0/). 